\title{
The Performance of Protected Mutual Funds in Indonesia During Covid-19 Period
}

\author{
Tinjung Desy Nursanti ${ }^{1, *}$ Nugraha $^{2,}$ Maya Sari ${ }^{3}$ Ika Putera Waspada ${ }^{4}$ \\ ${ }^{1}$ Universitas Pendidikan Indonesia \\ ${ }^{2}$ Universitas Pendidikan Indonesia \\ ${ }^{3}$ Universitas Pendidikan Indonesia \\ ${ }^{4}$ Universitas Pendidikan Indonesia \\ ${ }^{*}$ Corresponding author.Email: tinjungdesy@upi.edu
}

\begin{abstract}
Mutual funds are considered the right choice for investors who have limited time, ability, and knowledge in calculating the risk of investing. The more widely disclosed information obtained is inseparable from the application of digital technology related to the marketing strategy of mutual fund products by investment managers. The net asset value of mutual funds until the end of 2019 can be achieved as much as 555 trillion rupiahs. In the last 20 years, total assets under management of mutual funds (AUM) have increased from 5.14 trillion rupiahs in 1999 to 543.76 trillion rupiahs in 2019, with the largest contributor to managed funds coming from protected funds with a total of 153.91 trillion rupiahs. Amid the Covid-19 pandemic, as of March 2020, the mutual fund industry experienced pressure as seen from the decline in AUM, followed by a decrease in participation units. The decrease in AUM occurred in al-most all mutual funds. However, the smallest reduction in AUM occurred in protected funds. Therefore, the protected mutual fund instrument is a preferred product compared to other mutual funds, especially fixed-income funds, because the worstcase scenario occurs only when bond issuing companies experience defaults. Through literature study, this research aims to determine whether protected mutual funds in Indonesia will continue to share an upward trend in the future even though the covid-19 period is not over. The likelihood that can occur is whether protected mutual funds will be outperformed or underperformed.
\end{abstract}

Keywords: Protected Mutual Funds, Assets Under Management, Covid-19 Pandemic, Literature Study.

\section{INTRODUCTION}

\subsection{Mutual Funds Industry}

Based on the annual report from OJK, it is known that the capital market capitalization value since reactivated in 1977 has increased significantly until 2019. The upward trend from year to year at least reflects the increasing interest of investors investing in Indonesia. Meanwhile, as an alternative investment today, mutual funds are the best choice for many investors who do not have much experience or extensive knowledge in its management. Moreover, the number of investors registered (Single Investor Identification/ SID) in the mutual fund industry at the end of 2019 was $1,774,493$. That number is up $78.25 \%$ from 2018 , which is 995,510 investors. It means the interest of potential investors is raised relatively high. OJK reports that the growth in the number of mutual fund investors tends to be caused by the digitalization of the marketing of products offered or the emergence of companies engaged in financial technology (fintech). Thus, it can be said that mutual funds can be one of the solutions for novice investors. After all, mutual fund investments are seen as a safe instrument, supervised directly by the OJK, managed by profession-al investment managers, providing profitable returns to minimal investment because they are very affordable and can be purchased starting from Rp. 10,000.-. Meanwhile, judging from the product's characteristics, mutual funds are considered suitable for individuals or people categorized as young people or millennials be-cause the purchasing process is fast, easy, practical, and can be done through a mobile application. 
Compared to Indonesia's population, which is close to 267 million, the proportion of Indonesian investors investing in the capital market and mutual funds is still tiny, which is only around $0.8 \%$. The population in several ASEAN countries, which are capital market investors and mutual funds, can reach a range of $20 \%$ of the total population. This shows that Indonesia still has excellent potential related to investment in the capital market and the types of assets that can be offered.

During the Covid-19 pandemic, the mutual funds industry experienced the pressure that can be seen from the decline in assets under management, followed by a de-crease in participation units. However, the smallest reduction in AUM occurred in protected funds. Nevertheless, based on the return, the highest index returns of year-to-date mutual funds until September 2019 were fixed-income funds of $7.01 \%$, money market funds of $3.96 \%$, mixed funds of $2.17 \%$, and stock mutual funds that declined to $-8.38 \%$. Several market responses to shifting funds from equity funds to fixed-income funds were followed by the fall in return on equity funds. In this case, available funds were invested in Government Securities Bond (SBN), given the momentum of a decline in the benchmark interest rate.

\subsection{The Basic Concept of Protected Funds}

A protected Fund (RDT) is a type of mutual fund that protects investors' initial investment value through a portfolio management mechanism.

In other words, a protected fund is a mutual fund whose principal value of the investment is protected if disbursed at the end of the agreement period. This mutual fund protects the initial investment deposited. If the investor makes a disbursement before the agree-ment period, it will suffer a loss because it does not make the initial principal value of the investment equal to the end of the investment period [1]. Usually, investments are made in fixed income as-sets that have a certain period, such as bonds. Until the end of 2019, it is listed that there are 988 types of protected funds.

Meanwhile, when viewed from the return, the highest return index of mutual funds year-to-date until September 2019 is fixed income funds of $7.01 \%$. Protected mutual funds are valued as a safe investment because it protects the investor's initial investment value or money until the due date. Besides, investors can also profit before the due date tempo, which starts from three months, six months, and one year.

Protected mutual funds became the most outstanding product based on OJK statistical data as of March 2020 reached 988 products with a managed fund of Rp. $150,816,979$. This indicates that the community is quite enthusiastic about mutual fund products protected. In investing, investors will be faced with two things, namely return and also a risk. This encourages investors to do the performance appraisal of their investment instruments in terms of returns and risks, whether the risk is borne under the return obtained. But no all investors can carry out calculations and performance analysis for instruments investment. Protected funds can only invest in debt securities categorized as investment-worthy with a BBB minimum rating [2]

Based on the Financial Services Authority (OJK) web-site's latest data, the number of products and Net Asset Value (NAV) mutual funds fluctuates. The amount of managed funds or mutual fund NAV from November 2019 to March 2020 continues to decline.

Based on sources from www.invest.kontan.co.id (2019), that funds managed by the mutual fund industry fell as of November 2019 mainly due to the decline in equity funds, mainly due to the number of mutual fund dissolutions related to the Narada Asset Management case. Moreover, IHSG also experienced to de-cline, which triggered a decrease in a mutual fund man-aged funds. The decline of mutual funds' assets under management continues in a row in January, February, and March 2020, Rp.537,279, Rp. 525,277 and Rp. 472,772. Furthermore, quoted from www.market.bisnis.com (2020), the mutual fund industry since the beginning of 2020 has been exposed to market turmoil capital caused by the Jiwasraya case and added to the plague of coronavirus (Covid-19 pandemic) so that the impact on the IHSG decrease by 18.18 percent in the current year and also the depreciation in net asset value mutual fund.

Understanding the types of mutual funds is essential for potential investors because every mutual fund has different level characteristics, determined by its return and risk. Protected mutual funds are similar in characteristics to safe deposits because they have a maturity period and share benefits periodically [3]. An investment strategy in protected mutual funds is done passively, where investors buy bond instruments and then hold them until the due date.

\section{METHODS}

The method used in this research is a literature review, a comprehensive study, and interpretation of literature that addresses a specific topic, in this case, the performance of protected mutual funds in Indonesia during the Covid-19 pandemic (Aveyard, 2010). The steps used are as follows: narrowing the topic and selecting previous studies, consequently, searching the literature and reading the articles thoroughly, and then evaluating them, as well as organizing the selected papers. 


\subsection{Literature Studies: The Rise of Protected Funds' Demands}

Protected Funds (RDT) are becoming popular because their returns are more transparent about the coupon of debt securities used by the underlying assets. Further-more, amid the Covid-19 pandemic, as of March 2020, the mutual fund industry is experiencing pressure. It can be seen from the decrease in assets under management (AUM) followed by a decrease in units' inclusion. The decline in AUM occurs in almost all types of mutual funds. However, it was noted that the smallest drop in AUM occurred in protected mutual funds.

Protected fund products are more popular than any other type of mutual fund, especially fixed-income funds, because the worst-case scenario occurs only when the bond issuing company is experiencing de-fault. The high demand for protected funds indicates that the community is quite enthusiastic about protected mutual fund products. In investing, investors will be faced with two things, namely returns and risks. This encourages investors to assess their investment instruments performance in terms of returns and risk, whether the risk is borne under the return obtained. But not all investors can do performance calculations and analysis for their investment instruments.

\subsection{Previous Studies}

Several studies on the influence of internal factors, namely the variable performance of mutual funds in the previous period, show contradictory results. Some research results show that past mutual fund returns affect current mutual fund performance [4]-[7]. While the results of reference [8] Bogle's research (1994) show the opposite results, in this case, past performance appraisal does not provide adequate results on the performance of current mutual funds. The study results are related to several macroeconomic variables that are estimated to affect mutual fund performance, which tend to show contradictory results, including the interest rates of SBI. The results of the previous study stated that the interest rate affects mutual fund performance[8], [9], while the results reference [10] noted that the exchange rate did not affect mutual fund performance.

The inflation variable, which is a measure of high and low living costs, also gives different results. Research conducted by [11] found that mutual fund returns are susceptible to inflation. In comparison, a study conducted by [12] showed a positive influence between inflation rates and mutual funds, while in Romania, the relationship between inflation rates and mutual funds could not be proven. Reference [8] shows that there is a negative relationship between inflation rates and mutual fund performance. Some recent studies in Indonesia concerning mutual funds have been carried out, among others [13], which examines the determinants of mutual funds in Indonesia, emphasizing the ability or skill factors of investment managers. His study results showed that the determinants tested (including total risk, systematic risk, fund age, size, stock selection, market timing, and expenses ratio) produced a significant relationship between total risk, fund age, stock selection, market timing with fund performance. In contrast, systematic risk and fund size did not find a significant relationship with fund performance.

As for investors who invest in mutual funds in Indonesia during the period 1/1/2008 - 31/3/2011, the selection criteria that are expected to provide the best results are mutual funds with low total risk, long-standing mutual funds, long-standing ability to select stocks (no determined whether he is an old player or a new player) and a low load ratio. As for other studies examining the main criteria of domestic (Indonesian) investors in mutual fund selection behavior and evaluating their performance through survey methods and using a questionnaire, the findings show that there are seven (7) main factors that influence various types of investors in mutual fund selection behavior [14]. These include characteristics related to mutual funds, the reputation of mutual fund images, flexibility to facilitate investment, performance, popularity, transparency, and non-cash benefits.

Another important aspect of this research is the feasibility analysis of various groups of investors (professional, ambitious, moderate, conservative, and careful) of the seven factors. Other research related to the characteristics of mutual funds and the performance of equity funds in Indonesia which aims to understand the effect of mutual fund characteristics which include expenditure ratios, mutual fund size, turnover ratios, and age of mutual funds to the performance of mutual funds in Indonesia [15]. The study results are that the ratio of spending and age of mutual funds has a significant negative effect on Indonesia's performance of equity funds. In contrast, the size of mutual funds and turnover ratios significantly impact Indonesia's performance of equity funds.

Meanwhile, other research related to evaluating the performance of 31 growth-oriented mutual funds based on weekly NAV and weekly closing prices compared to the rate of return in Bangladesh [16]. It produced findings that during the study period, selected mutual funds showed a large negative rate of return and a declining trend when compared to market returns. This research emphasizes the point of view of investors and the market, which stated that the Treynor ratio, Sharpe ratio, and alpha Jensen are used to evaluate the mutual fund's performance. The results of other studies also conducted in emerging markets, namely Pakistan, are related to determinants of mutual fund performance, resulting in findings that expenditure is positively correlated with returns. Mutual fund sizes show a positive correlation 
with returns, but a low level of significance indicates that their relationship is not explained in the model. Basically, this study discusses the effect of various mutual fund characteristics on mutual fund returns [17].

Research related to the characteristics of mutual funds and investment performance in India was also carried out [18]. Based on the results of the panel regression using fixed-effect estimators, it can be shown that the size of the mutual fund, growth in the size of the mutual fund, and NAV affect negatively one period ahead performance risk-adjusted in India, while the age of mutual funds has a positive impact. Expenditures and portfolio ratios do not play an essential role in mutual fund performance. Meanwhile, recent research related to the evaluation of investment performance in mutual funds in Portugal that aims to contribute to research developed by identifying determinants of mutual fund investment performance in Portugal [19]. The results of his research show the findings that variables such as risk, rotation, size, age, interest rates, commissions, and benchmarks as determinants of mutual fund performance are very significant which, if followed by mutual fund managers, will be able to in-crease the number of expected returns.

Reference [20] conducted a study on the valuation of equity funds' performance in Indonesia using the Sharpe Index, Treynor Index, Jensen Index, Sortino Ratio, Adjusted Sharpe Index, and Adjusted Jensen Index period January 2012 - December 2014. The results of this study are based on the four measurement methods. SAM Indonesia Equity stock mutual funds consistently show the best performance in the first place. Meanwhile, reference [21] also conduct research on equity funds' performance analysis using the Sharpe, Treynor, and Jensen. The research used 58 samples of equity mutual funds, mutual funds which consistently performed positively and outperformed throughout the study period viz 2012 - 2014 were RHB OSK Alpha Sector Rotation and SAM Indonesian Equity Fund.

Research on the performance of mutual funds globally was carried out by reference [22] related to mutual funds' strength based on international diversification in multinational corporate mutual funds. Their study produced findings that support the hypothesis that diversification of global portfolios from multinational companies reduces transaction costs and information investing abroad. Furthermore, reference [23] propose a new approach that is the prob-ability of outperformance as a new performance measure, which can be used to compare strategies with specified benchmark sizes and develop maximum likelihood predictors' basic statistical properties in the Brownian motion framework). Their findings are used to investigate the question of whether mutual funds can defeat the S\&P 500 or Russell 1000. Most of the funds considered are, in fact, capable of beating the market.
Frahm \& Huber argues that one must refer to differential returns when comparing strategies with given benchmark measures and not comparing strategies and benchmarks with financial markets. This explains why mutual funds often seem to perform poorly in the market, but this conclusion is not entirely accu-rate. More research is needed. This research aims to determine whether protected mutual funds in Indonesia will continue to experience an upward trend in the future even though the covid-19 period is not over. The likelihood that can occur is whether protected mutual funds will be outperformed or underperformed.

\section{RESULTS AND DISCUSSION}

Until July 2020, related to the IDX's trading activities, the average daily transaction value (RNTH) was recorded at IDR7.67 trillion / day, with a total average frequency and volume of trading transactions reaching 537 thousand times and 7.91 billion shares traded. Since 2018 , it is known that the average trading frequency on the IDX is the highest on the ASEAN Stock Exchange (https://www.idx.co.id/en-us/news/press-releasedetail/?emitenCode=1351).

During the Covid-19 pandemic, the Financial Services Authority (OJK) has determined a series of stimuli for capital market stakeholders. Besides, IDX, in collaboration with OJK and SRO, on August 10, 2020, has con-ducted a soft launch of the Indonesian Electronic Public Offering System (e-IPO). This facility can help the Initial Public Offering process be more efficient, effective, and transparent through a systems approach. This system is expected to increase the ease of access for investors to participate in the Main Market, from the price formation stage to the Public Offering, and increase investor confidence in the Public Offering and Initial determination process.

Even though the pandemic's hard times have yet to show signs of ending, the number of mutual fund investors continues to increase by the end of 2020. In particular, the increase in mutual funds investors has reached $30.50 \%$ than the previous year. Therefore, the protected mutual funds showed excellent performance during the pandemic of Covid-19 until today. It can be seen from the rising numbers of assets under management, the increasing number of investors, and the convenience supported by the OJK and IDX in doing online transactions. Refer to its characteristics of protected mutual funds, which is considered as a safe investment, since it protects the value or money of the investor's initial investment until the maturity date. In addition, investors can also get profits before the due date, starting from 3 months, 6 months, and 1 year. 


\section{CONCLUSIONS}

The ranking of mutual funds does not merely refer to profit-sharing but with risk considerations. Mutual fund performance appraisal can be done through a combination of qualitative and quantitative methods. Quantitative methods refer to performance and risk factors and investor confidence, e.g., by using a modified Sharpe ratio, total return, and growth of investment units. In contrast, the qualitative methods are more likely to be employed considering the performance of mutual funds that experienced anomalies and managed funds.

\section{REFERENCES}

[1] Tandelilin, Eduardus. "Pasar Modal: Manajemen portofolio \& investasi." 2017.

[2] Mandiri Manajer Investasi. (n.d.). Tentang Kami Mandiri Investasi. Retrieved May 6, 2020, from https://mandiri-investasi.co.id/id/tentang-kami/

[3] Maditiara, A., \& Nafik, M. Kinerja Reksadana Terproteksi Syariah dengan Indeks Sharpe, Treynor, dan Jensen (Periode tahun 2013-2016). Jurnal Ekonomi Syariah Teori Dan Terapan, 5(11), 955970, 2018 .

[4] Goetzmann, William N., and Roger G. Ibbotson. "Do winners repeat?" Journal of portfolio management 20, no. 2, (1994.

[5] Brown, Stephen J., and William N. Goetzmann. "Performance persistence." The Journal of finance 50, no. 2, 1995.

[6] Malkiel, Burton G. "Returns from investing in equity mutual funds 1971 to 1991." The Journal of finance 50, no. 2, 1995.

[7] Pástor, Luboš, and Robert F. Stambaugh. "Mutual fund performance and seemingly unrelated assets." Journal of Financial Economics 63, no. 3, 2002.

[8] Shukla, Ravi. "Bogle on Mutual Funds: New Perspectives for the Intelligent Investor.", 1994.

[9] Dima, B., Barna F., \& Nachescu, M. 2007. Macroeco-nomic Determinants of the Investment Fund Mar-ket: The Romanian Case. MPRA Paper No. 5802. Vol-ume 23, 1-62. Elsevier Ltd., ISSN: 0196-3821/doi:10.1016/S0196-3821(06)23001-6.

[10] Alshogeathri, Mofleh Ali Mofleh. "Macroeconomic determinants of the stock market movements: empirical evidence from the Saudi stock market." PhD diss., Kansas State University, 2011.

[11] Kumar, Alok, Alexandra Niessen-Ruenzi, and Oliver G. Spalt. "What's in a name? Mutual fund flows when managers have foreign-sounding names." The Review of Financial Studies 28, no. 8, 2015.

[12] Diaconasu, Delia Elena, and Alexandru Asavoaei. "The Relationship between Mutual Funds-Inflation Rate and Benchmark Interest Rate: USA Versus Romania.", 2011.

[13] Alexandri, M. B. (2015). Analysis of Mutual Funds Per-formance and Persistence in Indonesia. 4 (1), 2011-2015.

[14] Amiri, Haniyeh, and Ana Maria Gil-Lafuente. "Studying of the factors affecting on the mutual fund by individual investor in Iran, Malaysia, Turkey and US." Modern Applied Science 10, no. 9, 2016.

[15] Dwiprakasa, Bernadus, and Christiana Fara Dharmastuti. "Karakteristik Reksa Dana dan Kinerja Reksa Dana Saham di Indonesia." Jurnal Manajemen 13, no. 1, 2016.

[16] Siddik, Md Nur Alam, Gang Sun, Sajal Kabiraj, Joghee Shanmugan, and Cui Yanjuan. "Impacts of ebanking on performance of banks in a developing economy: empirical evidence from Bangladesh." Journal of Business Economics and Management 17, no. 6, 2016.

[17] Asad, M. (n.d.). Determinants of Mutual Funds Performance in Pakistan. 1-38., 2017.

[18]Babbar, S., \& Sehgal, S. (2018). Mutual Fund Character-istics and Investment Performance in India. https://doi.org/10.1177/0258042X17745183

[19] Amaral, F., Reis, P., \& Pinto, P. (2019). Evaluating in-vestment fund performance in Portugal.

[20] Pangestuti, I. R. D., Wahyudi, S., \& Robiyanto. (2017). Performance Evaluation of Equity Based Mutual Funds in Indonesia. Jurnal Keuangan dan Perbankan, 4, 527-542.

[21] Anggara, A. W., \& Yulianto, A. (2017). Analisis Kinerja Reksa Dana Saham dengan metode Sharpe, Treynor, dan Jensen. Management Analysis Journal, 6(1).

[22] Demirci, I., Ferreira, M. A., Matos, P., \& Sialm, C. (2019). How Global is Your Mutual Fund? International Di-versification from Multinationals.

[23]Frahm, G., \& Huber, F. (2019). The Outperformance Probability of Mutual Funds. (Kestner 1996), 1-29. https://doi.org/10.3390/jrfm12030108 